\title{
Bacteriophage-induced Sporulation in Bacillus cereus $\mathbf{T}$
}

\author{
By DON P. BOUDREAUX† AND V. R. SRINIVASAN* \\ Department of Microbiology, Louisiana State University, Baton Rouge, Louisiana 70803, \\ U.S.A.
}

(Received 20 March 1981)

An oligosporogenic strain of Bacillus cereus $T$ was found to carry an inducible phage. $\mathrm{CsCl}$-ethidium bromide gradients of lysates of this strain contained satellite DNA of the same density as the phage genome. Neither the phage nor the satellite DNA could be detected in the sporogenic parental strain. Purified phage preparations increased sporulation from 10-50-fold when added to cultures of the oligosporogenic strain.

\section{IN TRODUCTION}

Among the wide range of regulatory functions proposed for extrachromosomal elements is the initiation of sporulation (Jacob et al., 1960). Rogolsky \& Slepecky (1964) reported that the treatment of sporogenic strains of Bacillus subtilis with acriflavin, an agent effective in curing cytoplasmically carried plasmids (Hirota, 1960), led to a 150-fold increase in the frequency of asporogenic mutants. These asporogenic strains were not altered for any function other than their ability to sporulate. Heat and ultraviolet light, other methods effective in curing bacteria of plasmids, also yielded oligosporogenic mutants altered in the initiation of sporulation (Norton \& Slepecky, 1967; Schaeffer et al., 1959).

This paper describes a bacteriophage carried by Bacillus cereus $\mathrm{T}$ which can induce sporulation in an oligosporogenic strain of this organism. The phage-carrying strain contains satellite DNA of the same buoyant density as the phage genome.

\section{METHODS}

Organisms and medium. An oligosporogenic strain (OSp) of Bacillus cereus $\mathrm{T}$ was isolated from a chemostat culture of the sporogenic parent $\left(\mathrm{Sp}^{+}\right)$. The isolation. growth and sporulation of the two strains have been described previously (Boudreaux \& Srinivasan. 1981). Strain OSp formed large, flat, non-mucoid colonies containing less than $1 \%$ spores after $96 \mathrm{~h}$. Conversely, colonies of strain $\mathrm{Sp}^{+}$were small, mucoid and contained greater than $95 \%$ free spores after $96 \mathrm{~h}$. Cells were maintained on plates of either $0.8 \%(\mathrm{w} / \mathrm{v})$ nutrient agar supplemented with $0.2 \%(\mathrm{w} / \mathrm{v})$ yeast extract or on glucose/glutamate $(\mathrm{GG})$ agar (Boudreaux \& Srinivasan, 1981).

Cultivation. Either heat-activated spores $\left(80^{\circ} \mathrm{C} .30 \mathrm{~min}\right.$ ) or vegetative cells from $24-36 \mathrm{~h} \mathrm{GG}$ agar plates were inoculated into $20 \mathrm{ml} \mathrm{GG}$ medium to give an initial $A_{600}$ of 0.05 . Flasks were incubated without shaking for $16 \mathrm{~h}$ at $23{ }^{\circ} \mathrm{C}$ and then shaken at $34{ }^{\circ} \mathrm{C}$ until the $A_{600}$ reached $2 \cdot 0$. This culture was used to inoculate fresh GG medium (using a $10 \%, v / v$ inoculum) and incubated at $34{ }^{\circ} \mathrm{C}$ until the desired cell density was reached.

Phage induction and purification. Bacteriophage were induced with either ultraviolet (u.v.) light or mitomycin C. For u.v. induction, the culture was placed in an uncovered Petri dish, to a depth of less than $0.5 \mathrm{~cm}$, and swirled 10 $\mathrm{cm}$ below a $15 \mathrm{~W}$ germicidal lamp (General Electric Co.) for $30 \mathrm{~s}$. The u.v.-treated culture was returned to the growth flask and incubated at $34^{\circ} \mathrm{C}$ for $3 \mathrm{~h}$. For mitomycin $\mathrm{C}$ induction, the drug was added to the culture $\left(A_{600}\right.$ 0.75 ) to give $1 \mu \mathrm{g} \mathrm{ml}^{-1}$, followed by incubation at $34{ }^{\circ} \mathrm{C}$ for $3 \mathrm{~h}$. In both cases the cells were then removed by centrifuging at $3000 \mathrm{~g}$ for $30 \mathrm{~min}$. EDTA was added to the supernatant to a concentration of $10 \mathrm{~mm}$ and phage were recovered by centrifuging under conditions sufficient to remove particles larger than $50 \mathrm{~S}$. The $50 \mathrm{~S}$ pellet was resuspended in $0.2 \mathrm{ml}$ of a saline/Tris/EDTA buffer (STE: $0.15 \mathrm{M}-\mathrm{NaCl}$. 0.05 $\mathrm{M}$-Tris and $5 \mathrm{~mm}$-EDTA adjusted

\footnotetext{
† Present address: Laboratory of Molecular Biology, NINCDS, NIH, Bethesda, Maryland 20205. U.S.A.
} 
to $\mathrm{pH} 7.5)$ and layered on a preformed gradient of 5-20\% (w/v) sucrose in STE buffer. Gradients were centrifuged in a Beckman SW65 rotor $\left(4^{\circ} \mathrm{C}\right)$ for $90 \mathrm{~min}$ at $25000 \mathrm{rev}$. $\mathrm{min}^{-1}(45000 \mathrm{~g})$. Fractions of $0 \cdot 1 \mathrm{ml} \mathrm{were}$ collected from the bottom of the tube. Bacteriophage were detected by either electron microscopy or absorbance at $260 \mathrm{~nm}$.

DNA containing $\left[{ }^{3} \mathrm{H}\right]$ adenosine was prepared in GG medium supplemented with $0.05 \%$ (w/v) yeast extract and $10 \mu \mathrm{Ci}\left[{ }^{3} \mathrm{H}\right.$ ]adenosine $\mathrm{ml}^{-1}$ [specific activity $\left.5 \mathrm{Ci} \mathrm{mol}^{-1}\left(185 \mathrm{GBq} \mathrm{mol}^{-1}\right)\right]$. The cultures were inoculated at an $A_{600}$ of 0.05 and kept stationary at room temperature for $12 \mathrm{~h}$, and then transferred to $34^{\circ} \mathrm{C}$ and shaken for $4 \mathrm{~h}$ by which time the $A_{600}$ reached 1.5 . The cells were harvested by centrifugation $(3000 \mathrm{~g}, 30 \mathrm{~min})$, washed twice with STE buffer and prepared for isopycnic centrifugation as described by Lovett (1973). Gradients were centrifuged in a Ti50 rotor $\left(15^{\circ} \mathrm{C}\right)$ at $36000 \mathrm{rev} \cdot \mathrm{min}^{-1}(86000 \mathrm{~g})$ for $42 \mathrm{~h}$. Fractions of $0.1 \mathrm{ml}$ were collected from the bottom of the tube. Samples $(10 \mu \mathrm{l})$ of each fraction were spotted on Whatman no. 1 filter paper circles, dried at $80^{\circ} \mathrm{C}$ and the radioactivity was determined by liquid scintillation spectrometry. Extrachromosomal DNA was demonstrated by isopycnic centrifugation with and without ethidium bromide as described by Lovett (1973).

\section{RESULTS AND DISCUSSION}

\section{Phage induction}

Plate counts of cultures of the sporogenic strain typically exhibited a spontaneous $\mathrm{Sp}^{+} \rightarrow$ OSp conversion frequency of $0.03 \%$ (scored by colony morphology). No spontaneous OSp $\rightarrow \mathrm{Sp}^{+}$conversion could be detected. The high rate of generation of OSp colonies from the $\mathrm{Sp}^{+}$strain, the observation of sectored colonies and the pitted nature of old colonies of the OSp strain suggested the possible involvement of a phage in this conversion. Induction of strain OSp with u.v. light or mitomycin C liberated a phage (Fig. 1). The phage had a hexagonal head (45 nm diameter) and a rigid tail (145 nm long) with a whip-like appendage similar to that of Bacillus subtilis phage PBS1. Isopycnic centrifugation in $\mathrm{CsCl}$ showed the phage density to be 1.595; the density of the phage DNA in $\mathrm{CsCl}$ was 1.630 . Induction of the $\mathrm{Sp}^{+}$parent did not liberate any phage-like particles as determined by electron microscopic examination of the concentrated culture supernatants. Attempts to obtain either a phage-sensitive host or a phage mutant (i.e. temperature-sensitive repressor) which yielded high titre lysates were not successful.

\section{Strain OSp contains extrachromosomal DNA}

$\mathrm{CsCl}$-ethidium bromide analysis of crude lysates of strains $\mathrm{Sp}^{+}$and $\mathrm{OSp}$ was conducted to detect the presence of extrachromosomal DNA. Cultures of the two strains were labelled with $\left[{ }^{3} \mathrm{H}\right]$ adenosine as described in Methods. Strain OSp was found to contain a satellite peak at a position corresponding to a lower density than that of the primary peak (Fig. 2). The satellite peak contained about $2.5 \%$ of the counts found in the main peak. No satellite DNA could be detected in lysates of strain $\mathrm{Sp}^{+}$. Fractions corresponding to the main peak and the satellite peak were pooled separately. The ethidium bromide was removed by dialysis against STE buffer and the samples were again subjected to isopycnic centrifugation in $\mathrm{CsCl}$. The main peak had a density of 1.690 ; the satellite peak density was approximately 1.63 . Lysates of strain OSp subjected to equilibrium centrifugation in the absence of ethidium bromide showed an identical pattern of bands.

This observation that the distance between the satellite and main peak was the same in the presence and absence of ethidium bromide is important. A covalently closed molecule changes density less than non-covalently closed DNA in the presence of ethidium bromide. Thus, if the DNA in the satellite peak were covalently closed the distance between the satellite and the main peak in $\mathrm{CsCl}$-ethidium bromide gradients should decrease. The observations described above suggest that the satellite DNA is probably not a covalently closed molecule. Moreover, the buoyant densities of the phage genome and the satellite DNA in CsCl were both approximately 1.63 suggesting that the satellite peak and phage genome are identical. 


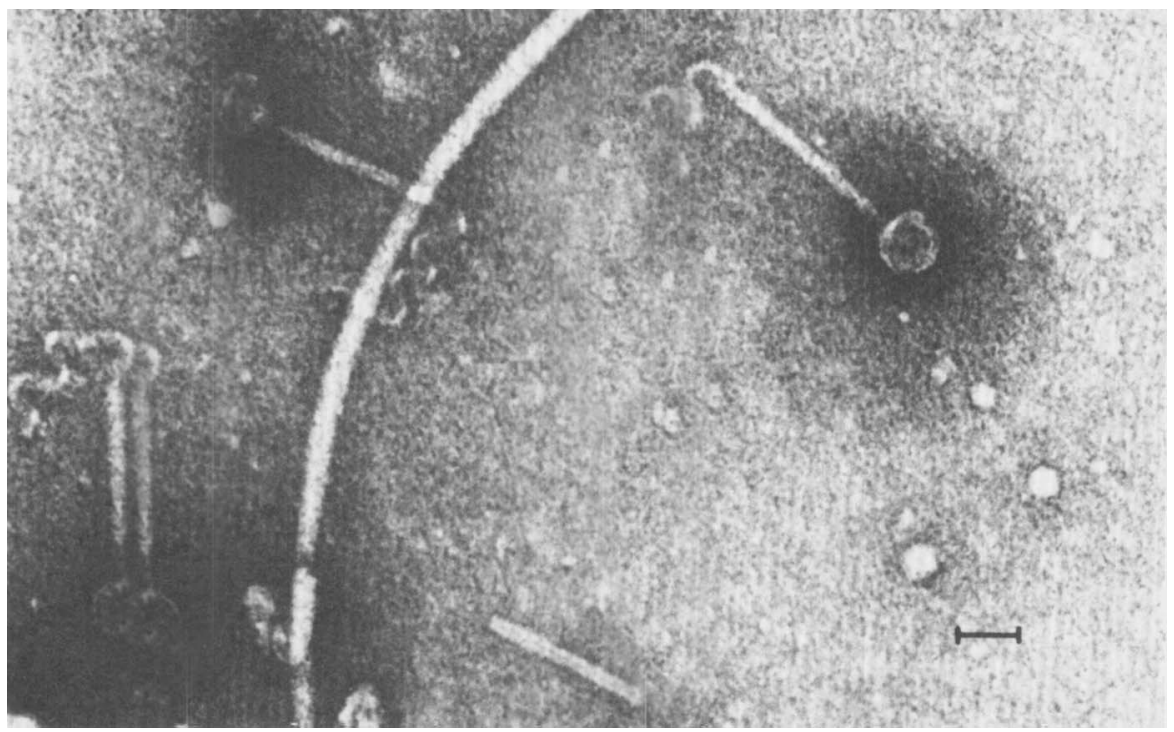

Fig. 1. Electron micrograph of a negatively stained preparation $\left(\mathrm{OsO}_{4}\right.$ fixation) of bacteriophage isolated from the oligosporogenic strain of Bacillus cereus T. Phage were induced with u.v. light and purified as described in text. The bar marker represents $50 \mathrm{~nm}$.

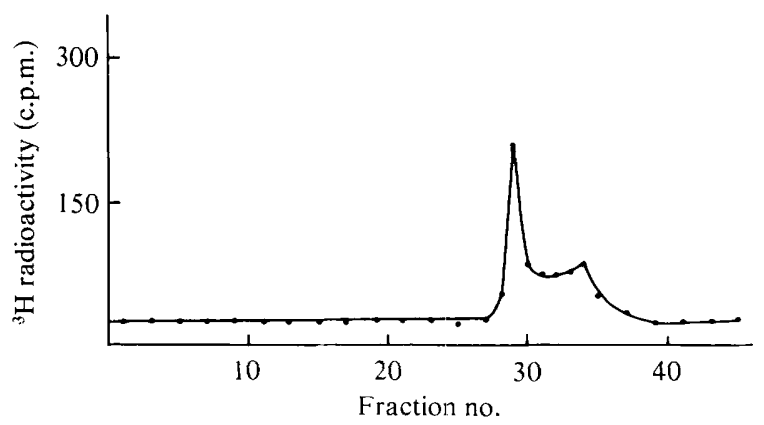

Fig. 2. CsCl-ethidium bromide gradient of a crude lysate of the oligosporogenic strain of Bacillus cereus $\mathrm{T}$. Cells were grown in minimal medium containing $\mid{ }^{3} \mathrm{H}$ ladenosine to an $A_{600}$ of 1.5 and then prepared for isopycnic centrifugation.

\section{Phage-enhanced sporulation of strain $O S p$}

Phage preparations were purified on sucrose gradients, dialysed exhaustively against $0.1 \mathrm{M}-\mathrm{K}_{2} \mathrm{HPO}_{4}\left(\mathrm{pH} \mathrm{7.0)}\right.$ and stored at $4{ }^{\circ} \mathrm{C}$ over chloroform. Addition of this phage preparation to exponential phase batch cultures $\left(A_{600} 0.75\right)$ of the oligosporogenic strain increased sporulation 10-fold (Table 1). Additions of dialysis buffer similarly stored in the presence of chloroform gave no increase in sporulation. Sporulation increased 50-fold when the purified phage preparation was added to cells of strain OSp grown in a chemostat culture at a dilution rate of $0.23 \mathrm{~h}^{-1}$. From 10 to $15 \%$ of the spores formed following infection of oligosporogenic cultures with purified phage produced colonies of the $\mathrm{Sp}^{+}$phenotype. Regardless of the growth conditions, a decrease in spore induction was observed at phage additions greater than $0.2 \mathrm{ml}$ per $5 \mathrm{ml}$ culture. The increased response of cells from continuous culture to the phage probably reflects differences in the metabolic character of cells grown under the two conditions. 
Table 1. Enhancement of sporulation frequency by the addition of phage to cultures of strain $O S p$

Batch culture: cells were grown in GG medium $(20 \mathrm{ml})$ as described in Methods. When the $A_{600}$ reached $0.75,5 \mathrm{ml}$ of culture was distributed to each of four flasks. Phage was added to the flasks as indicated, together with dialysis buffer to maintain constant volume. After shaking at $37^{\circ} \mathrm{C}$ for $24 \mathrm{~h}$, the spore titres were determined by heating dilutions of the culture at $80^{\circ} \mathrm{C}$ for $30 \mathrm{~min}$ and plating on nutrient agar plates.

Continuous culture: cells were grown in synthetic medium in a chemostat as described previously (Boudreaux \& Srinivasan, 1981) at a dilution rate of $0.23 \mathrm{~h}^{-1}$ : the limiting nutrient was glucose. Then 5 $\mathrm{ml}$ of culture was distributed to each of three sterile flasks and phage was added. After shaking at $37^{\circ} \mathrm{C}$ for $24 \mathrm{~h}$, the spore titre was determined as described above.

$\begin{array}{lccccc} & \begin{array}{c}\text { Phage } \\ \text { added } \\ (\mathrm{ml})\end{array} & \begin{array}{c}10^{-8} \times \\ \text { Viable } \\ \text { titre* }\end{array} & \begin{array}{c}10^{-6} \times \\ \text { Spore } \\ \text { titre }\end{array} & \begin{array}{c}\text { Spore } \\ \text { frequency } \\ (\%)\end{array} & \begin{array}{c}\text { Relative } \\ \text { increase } \\ \text { in spore } \\ \text { Batch culture }\end{array} \\ 0.0 & 1.18 & 0.25 & 0.212 & - \\ & 0.1 & & 1.00 & 0.847 & 4.0 \\ & 0.2 & & 2.60 & 2.203 & 10.4 \\ \text { frequency }\end{array}$

*Viable counts were determined on the control culture at the time the phage was added.

The presence of extrachromosomal DNA and the ability to induce phage appear to be related. Previous reports have described phages which restore the ability to sporulate to oligosporogenic strains (Bramucci et al., 1977; Perlak et al., 1979). Additionally, plasmid involvement in sporulation has also been reported (Lovett, 1973). There are obvious differences between these systems and the one we present. Unlike the phage we describe, the previously reported phages were randomly isolated and probably represent generalized transducing phages. The plasmid associated with sporulation in Bacillus pumilus was not integrated into sporogenic revertants and no spontaneous $\mathrm{Sp}^{+} \rightarrow$ OSp conversion could be demonstrated (Lovett, 1973; Lovett \& Bramucci, 1974). Lovett (1973) thus proposed that the plasmid suppressed sporulation and that information carried by the plasmid was lost by the sporogenic strain. Conversely, our ability to demonstrate both a spontaneous $\mathrm{Sp}^{+} \rightarrow \mathrm{OSp}$ conversion and a phage-mediated reversion $\left(\mathrm{OSp} \rightarrow \mathrm{Sp}^{+}\right)$shows that no information is lost in the Bacillus cereus system.

\section{REFERENCES}

Boudreaux, D. P. \& Srinivasan, V. R. (1981). A continuous culture study of growth of Bacillus cereus T. Journal of General Microbiology 122, $129-136$.

Bramucci, M. G., Keggins, K. M. \& Lovett, P. S. (1977). Bacteriophage conversion of spore-negative mutants to spore-positive in Bacillus pumilus. Journal of Virology 22, 194-202.

Hirota, Y. (1960). The effect of acridine dyes on mating type factors in Escherichia coli. Proceedings of the National Academy of Sciences of the United States of America 46, 57-64.

Jacob, F., Schaeffer, P. \& Wollman, E. L. (1960). Episomic elements in bacteria. Symposia of the Society for General Microbiology 10, 67-91.

LovetT, P. S. (1973). Plasmid in Bacillus pumilus and the enhanced sporulation of plasmid negative variants. Journal of Bacteriology 115, 291-298.
Lovett, P. S. \& Bramucci, M. G. (1974). Biochemical studies of two Bacillus pumilus plasmids. Journal of Bacteriology 120, 488-494.

Norton, J. \& Slepecky, R. A. (1967). Sporulation mutations induced by heat in Bacillus subtilis. Nature, London 155, 838-839.

Perlak, F. J., Mendelsohn, L. \& Thorne, C. B. (1979). Converting bacteriophage for sporulation and crystal formation in Bacillus thuringiensis. Journal of Bacteriology 140, 699-706.

Rogolsky, M. \& Slepecky, R. A. (1964). Elimination of a genetic determinant for sporulation of Bacillus subtilis with acriflavin. Biochemical and Biophysical Research Communications 16, 204-208.

SCHAEFFER, P., IONESCo, H. \& JACOB, F. (1959). Sur le déterminisme génétique de la sporulation bactérienne. Comptes rendus hebdomadaire des séances de l'Académie des Sciences 249, 577-578. 